Loring, P. H., R. A. Ronconi, L. J. Welch, P. D. Taylor and M. L. Mallory. 2017. Postbreeding dispersal and staging of Common and Arctic Terns throughout the western North Atlantic. Avian Conservation and Ecology 12(2):20. https://doi.org/10.5751/ACE-01086-120220

Copyright (C) 2017 by the author(s). Published here under license by the Resilience Alliance.

Research Paper

\title{
Postbreeding dispersal and staging of Common and Arctic Terns throughout the western North Atlantic
}

\author{
Pamela H. Loring ${ }^{1,2}$, Robert A. Ronconi ${ }^{3,4}$, Linda J. Welch ${ }^{5}$, Philip D. Taylor ${ }^{3}$ and Mark L. Mallory ${ }^{3}$ \\ ${ }^{1}$ University of Massachusetts Amherst, ${ }^{2}$ U.S. Fish and Wildlife Service Division of Migratory Birds, Northeast Region, ${ }^{3}$ Acadia \\ University, Canada, ${ }^{4}$ Canadian Wildlife Service, Environment and Climate Change Canada, ${ }^{5}$ U.S. Fish and Wildlife Service, Maine \\ Coastal Islands NWR
}

\begin{abstract}
In the western North Atlantic, Common (Sterna hirundo) and Arctic (S. paradisaea) Terns are sympatric at breeding colonies but show divergent migration strategies to coastal areas of South America and pelagic regions of the Antarctic, respectively. During 2013, we studied postbreeding movements of adult Common $(\mathrm{n}=130)$ and Arctic $(\mathrm{n}=52)$ Terns from four breeding colonies in the eastern USA and Canada using digital very high frequency (VHF) transmitters and an array of 62 automated radio telemetry towers. Relative to hatch dates at respective colonies, Arctic Terns departed breeding sites an average of eight days later than Common Terns. Common Terns were detected during the postbreeding period by coastal towers upward of $850 \mathrm{~km}$ south of their original nesting sites. The telemetry array detected postbreeding movements of Arctic Terns from the Petit Manan Island colony in the Gulf of Maine as they traveled eastward past Nova Scotia, Canada, mostly during the night. Nantucket Sound, Massachusetts, USA was identified as an important staging area for Common Terns from all colonies, whereby $26 \%$ of 53 tagged Common Terns from colonies in the Gulf of Maine and Canada were detected for up to three weeks. Common Terns typically arrived at Nantucket Sound within $2 \mathrm{~h}$ of sunset, 2 to 10 days after their last detection at Gulf of Maine and Canadian colonies, suggesting rapid postbreeding dispersal. Postbreeding dispersal of Arctic Terns was poorly documented with the telemetry array, suggesting that this species is not using coastal sites for staging, and is instead departing directly from colonies to offshore staging areas prior to long-distance migrations. We conclude that digital VHF telemetry is a useful method for monitoring regional movements of Common Terns, but additional offshore receiving stations are needed to effectively monitor movements of Arctic Terns away from their nesting colonies.
\end{abstract}

\section{Dispersion postnuptiale et haltes migratoires des Sternes pierregarin et arctique dans l'ouest de I'Atlantique Nord}

RÉSUMÉ. Dans l'ouest de l'Atlantique Nord, les Sternes pierregarins (Sterna hirundo) et arctiques ( $S$. paradisaea) nichent en colonies de façon sympatrique, mais adoptent des stratégies de migration différentes vers les régions côtières de l'Amérique du Sud et les régions pélagiques de l'Antarctique, respectivement. En 2013, nous avons étudié les déplacements postnuptiaux de Sternes pierregarins (n = 130) et arctiques $(n=52)$ adultes provenant de quatre colonies dans l'est des États-Unis et du Canada, au moyen d'émetteurs numériques à très haute fréquence $(\mathrm{VHF})$ et d'un réseau de 62 tours de radio-télémétrie automatisées. Selon les dates d'éclosion aux colonies respectives, les Sternes arctiques ont quitté les sites de nidification en moyenne 8 jours plus tard que les Sternes pierregarins. Durant la période postnuptiale, les Sternes pierregarins ont été détectées par les tours côtières jusqu'à $850 \mathrm{~km}$ au sud de leurs sites de nidification. Le réseau de télémétrie a détecté les déplacements postnuptiaux de Sternes arctiques de leur colonie de l'île Petit Manan, dans le golfe du Maine, au moment où elles se déplaçaient vers l'est au large de la Nouvelle-Écosse, Canada, le plus souvent durant la nuit. Le détroit de Nantucket, Massachusetts, É.-U., a été identifié comme halte migratoire importante pour les Sternes pierregarins en provenance de chaque colonie : $26 \%$ des 53 Sternes pierregarins suivies dans les colonies du golfe du Maine et du Canada y ont été détectées pour une période allant jusqu'à 3 semaines. Les Sternes pierregarins arrivaient généralement dans le détroit de Nantucket dans les deux heures précédant le coucher du soleil, de 2 à 10 jours après leur dernière détection aux colonies du golfe du Maine et du Canada, indiquant une dispersion postnuptiale rapide. La dispersion postnuptiale des Sternes arctiques n'a été que très peu captée par le réseau de télémétrie, ce qui laisse croire que cette espèce n'utilise pas de sites côtiers comme haltes migratoires, mais quitte plutôt les colonies pour se rendre directement à des haltes au large, avant d'entreprendre leur migration de longue distance. Nous concluons que la télémétrie numérique VHF est une méthode pratique pour suivre les déplacements régionaux des Sternes pierregarins; des stations réceptrices sont toutefois nécessaires au large pour suivre adéquatement les déplacements des Sternes arctiques au moment où elles quittent leurs colonies de nidification.

Key Words: Arctic Tern; automated radio telemetry; Common Tern; dispersal; seabird; staging; Sterna hirundo; Sterna paradisaea; very high frequency (VHF) tags 


\section{INTRODUCTION}

During the postbreeding period, seabirds use various dispersal and staging strategies to build energy reserves for migration (Huettmann and Diamond 2000, Klaassen et al. 2012, Montevecchi et al. 2012). High-quality staging areas provide sufficient space for roosting aggregations, abundant prey, and minimal disturbance by humans and predators (Warnock 2010). Species that disperse along the coast may use persistent staging areas with reliable roosting and foraging habitats (Trull et al. 1999), whereas species that roost and feed offshore may use dynamic staging areas in response to patchy prey distributions (Suryan et al. 2006, Guilford et al. 2009, Hedd et al. 2012). Advances in tracking technologies are increasing our understanding of the connectivity between nesting populations and staging areas of seabirds (Mosbech et al. 2012, Gilg et al. 2013, van der Winden et al. 2014). However, detailed information on postbreeding dispersal and staging movements is lacking for many species of seabirds, such as the small-bodied terns, because of limitations of the spatial and temporal resolution of lightweight tracking devices (Bridge et al. 2011).

In the western North Atlantic, from southern Labrador, Canada $\left(52^{\circ} \mathrm{N}\right)$ to Cape Cod, Massachusetts, USA $\left(41^{\circ} \mathrm{N}\right)$, the breeding ranges of Common (Sterna hirundo) and Arctic (S. paradisaea) Terns overlap and the two species nest sympatrically on nearshore and offshore islands (Kress et al. 1983, Gaston et al. 2009). The wintering ranges of these populations are geographically separated, with Common Terns wintering along the coasts of Central and South America (Hays et al. 1997, Nisbet et al. 2011a), and Arctic Terns wintering along the Antarctic pack ice (Hatch 2002). The migratory routes of the two species differ substantially. Austin (1928) proposed that Arctic Terns used an oceanic route to get to their (then unknown) wintering areas, based on observations during August between Ireland and Newfoundland from a ship at sea. Salomonsen (1967) assessed the state of the knowledge of the migration and wintering areas of Arctic Tern and provided evidence for an easterly movement of the species from the northeastern North American breeding populations during autumn. The oceanic route is also consistent with the sparse records for the species along the east coast of North America in the autumn (Lee and Cardiff 1993). In recent years, studies using archival light-level loggers (geolocators) have shown that Common Terns migrate south across the western North Atlantic toward Puerto Rico (Nisbet et al. 2011a) whereas Arctic Terns breeding in East Greenland stage in oceanic areas of the central North Atlantic (Egevang et al. 2010). Arctic Terns from breeding colonies in eastern North America stage offshore in the North Atlantic and then also follow an oceanic route to their wintering areas (L. Welch, unpublished data).

Prior to migration, mixed flocks of terns, primarily Common and Roseate (S. dougallii) Terns, stage at sites along the USA Atlantic coast from Maine through New Jersey (Shealer and Kress 1994, Nisbet 2002), with large flocks $>10,000$ terns reported on Cape Cod, Massachusetts (Trull et al. 1999). Consistent with their trans-Atlantic migratory route, Arctic Terns are rarely seen staging at these coastal sites, but are thought to stage at offshore sites, specifically Sable Island, Canada (Ronconi et al. 2016a), though it is not known if these staging birds are only from local colonies on the island or include breeding birds dispersing from mainland sites.
Although Common and Arctic Terns target similar species of prey fish and invertebrates (Rock et al. 2007) differences in the proportions of prey types consumed by each species, and differences in habitat use, with Common Terns tending to feed inshore and Arctic Terns tending to feed offshore, suggest a degree of resource partitioning (Braune and Gaskin 1982, Hall et al. 2000, Hatch 2002). These differences in habitat and foraging behavior, coupled with the known differences in their migratory routes, suggests that patterns of movement during the postbreeding season (postbreeding staging and dispersal) would likely differ between the species. Here we present the results of a study of the postbreeding movements of Common and Arctic Terns from four nesting colonies in the western North Atlantic extending from Nova Scotia, Canada to Massachusetts, USA.

The objectives of our study were the following: (1) to quantify the length of stay at four nesting colonies in the region, (2) to determine the extent to which individuals from those nesting colonies staged at sites within the telemetry array (specifically: South Monomoy Island off the coast of Cape Cod, Massachusetts, USA and Sable Island off the coast of Nova Scotia, Canada), and (3) to determine the timing and length of stay at these staging sites and the ultimate timing of departure from the study area. To accomplish these objectives, we employed digital Very High Frequency (VHF) radio transmitters and an array of coordinated automated radio telemetry stations (Motus telemetry array; Taylor et al. 2017) to track the postbreeding dispersal of these small-bodied seabirds at a regional scale.

\section{METHODS}

\section{Study area}

During 2013, we tagged individual terns at four breeding colonies ranging from northeastern Nova Scotia, Canada to

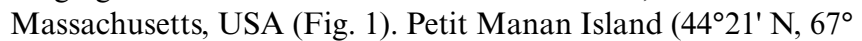
$52^{\prime} \mathrm{W}$ ) is a 6.5 -ha island situated approximately $4 \mathrm{~km}$ off the coast of Maine, USA and supports a mixed colony of about 1370 pairs of Common and Arctic Terns (GOMSWG 2013). Country Island $\left(45^{\circ} 06^{\prime} \mathrm{N}, 61^{\circ} 32^{\prime} \mathrm{W}\right)$, is a 19 -ha island located approximately 5 $\mathrm{km}$ off the east coast of Nova Scotia, Canada and contains a mixed colony of about 1,300 pairs of Common and Arctic Terns (GOMSWG 2013). Sable Island $\left(43^{\circ} 55^{\prime} \mathrm{N}, 60^{\circ} 00^{\prime} \mathrm{W}\right)$ is a $40-\mathrm{km}-$ long, crescent-shaped, 3400-ha island located approximately 180 $\mathrm{km}$ offshore from mainland Nova Scotia, Canada. Approximately 4200 pairs of Common and Arctic Terns nested in multiple colonies on Sable Island during recent surveys in 2013 (Ronconi et al. 2016b). Monomoy National Wildlife Refuge (NWR; $41^{\circ} 37^{\prime}$ $\mathrm{N}, 69^{\circ} 59^{\prime} \mathrm{W}$ ) is a 2800 -ha barrier beach and island complex located in the eastern Nantucket Sound region of Massachusetts, USA, approximately 400 to $800 \mathrm{~km}$ south of the other tern colonies included in this analysis. Situated within Monomoy NWR and < $5 \mathrm{~km}$ from the mainland coast of Cape Cod, South Monomoy Island supports one of the largest Common Tern colonies on the Atlantic coast, with over 7500 nesting pairs in 2013 (GOMSWG 2013). Small numbers ( $<18$ pairs) of Arctic Terns historically nested on the islands of Monomoy NWR, but have not since 1990 (United States Fish and Wildlife Service, unpublished data).

Among these study sites, two areas are documented or hypothesized as staging areas for terns prior to long-distance migrations. Monomoy NWR is centrally located within the outer 
Fig. 1. Map of 2013 study area in the western North Atlantic showing the locations of four tern breeding colonies (insets) and 62 automated radio telemetry stations, each consisting of directional antenna arrays mounted on masts or lighthouses (solid and open triangles, respectively) or omnidirectional antennas positioned in tern colonies (solid points).

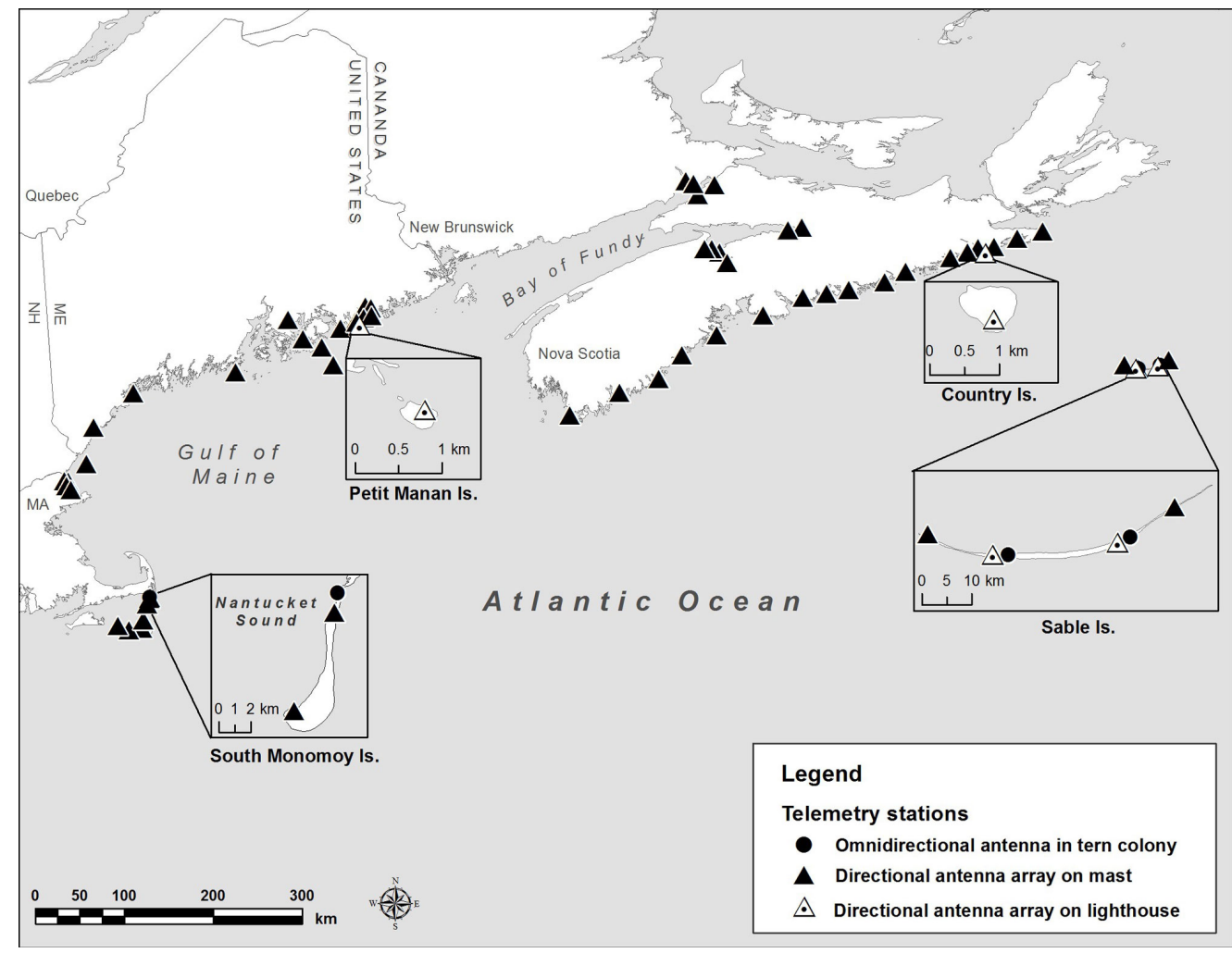

Cape Cod and Nantucket Sound region of Massachusetts, a welldocumented staging area for multiple species of terns in the western North Atlantic (Trull et al. 1999, Watson and Hatch 1999, Jedrey et al. 2010, Althouse et al. 2016). On Sable Island, the eastern and western ends, situated up to $15 \mathrm{~km}$ from the study colonies, are important foraging and roosting sites for both Common and Arctic Terns during the breeding season, and both species are thought to stage there during the postbreeding period (Ronconi et al. 2016a). We hypothesized that Sable Island may also be a staging area for terns departing mainland colonies because large numbers of Arctic and Common Terns use the distal ends of the island in August, and a Roseate Tern was detected here after breeding at a site in Massachusetts (Spendelow and McKnight, unpublished data as cited in Ronconi et al. 2016a).

\section{Automated radio telemetry}

In 2013, the Motus telemetry array (Taylor et al. 2017; http://www. motus-wts.org) was established at the four colony study sites and an additional 62 coastal and island sites, spanning nearly 1000 $\mathrm{km}$ of coastline from northeastern Nova Scotia to Cape Cod (Fig. 1). Each telemetry station was equipped with automated datalogging VHF receivers (SRX-600, Lotek Wireless Newmarket, $\mathrm{ON}$, or SensorGnome http://www.sensorgnome.org) connected to antennas using RG58 coaxial cable. Antennas included singlepole omni-directional, or an array of two to six directional (Yagi) antennas (five or nine element) mounted on lighthouses, $10-\mathrm{m}$ telescoping tripod poles, or other structures. Receivers were plugged into external AC power sources, or powered by solar panel arrays (one or two 55 or $65 \mathrm{~W}$ panels) connected to a battery bank (one to five 12VDC sealed lead acid batteries). Receivers monitored and recorded VHF signals from all tagged birds within detection range (typically $<20 \mathrm{~km}$ ) continuously from time of tagging at each site through to October (all sites) or December (Sable Island, Country Island, and some coastal sites).

\section{Tagging}

From early June to mid-July 2013, we used walk-in traps and bow nets to capture terns at their nest sites during the late incubation period through approximately three days following hatch. Across the four study sites, we deployed a total of 182 transmitters on 130 adult Common Terns and 52 adult Arctic Terns (Tables 1 and 2). All terns were tagged using digitally-coded VHF transmitters (Avian NanoTag series; Lotek Wireless, Newmarket, ON) that allowed over 500 individual identification codes to be monitored simultaneously on a single frequency $(166.380 \mathrm{MHz})$. Depending on the site, transmitters weighed between 1.2 to $1.5 \mathrm{~g}$ and were programmed with burst rate intervals that varied between 4.8 to 10.5 seconds, resulting in an expected tag life that ranged from 124 to 240 days. At each site, transmitters were attached to the interscapular region using cyanoacrylate adhesive and held in place with subcutaneous sutures that were secured to the transmitter through custom fit end-tubes (inner diameter $1 \mathrm{~mm}$ ). 
We assessed transmitter retention by searching for dropped transmitters within each tern colony, and by examining signals recorded by automated radio telemetry stations, where continuous detections by a single antenna over multiple days indicated a stationary tag. Individuals with dropped transmitters were excluded from subsequent analyses. However, we were unable to account for birds with dropped transmitters that were not recovered by field crews or that were dropped beyond detection range of the automated radio telemetry array.

Table 1. Sample sizes ( $n$ ) of Common (Sterna hirundo) and Arctic ( $S$. paradisaea) Terns fitted with digital VHF transmitters at four colonies in the western North Atlantic in 2013. Tagged $(n)$ indicates the starting sample size, and Final $(n)$ indicates the sample sized retained for subsequent analyses after removing (and in some instances redeploying) transmitters that were dropped.

\begin{tabular}{lcccccc}
\hline \hline & \multicolumn{2}{c}{ Tagged $(n)$} & & \multicolumn{2}{c}{ Final $(n)$} \\
\cline { 2 - 3 } \cline { 5 - 6 } Colony & Common & Arctic & & Common & Arctic \\
\hline Petit Manan Is. & 14 & 16 & & 14 & 15 \\
Country Is. & 15 & 15 & & 11 & 16 \\
Sable Is. & 29 & 21 & & 28 & 20 \\
Monomoy Is. & 72 & 0 & & 67 & 0 \\
Total & 130 & 52 & & 120 & 51 \\
\hline
\end{tabular}

\section{Data processing}

All analyses were conducted in $\mathrm{R}$ version 3.0.2 ( $\mathrm{R}$ Development Core Team 2016). We processed raw detection data using a burst rate filter in the $\mathrm{R}$ package "sensorgnome" (version 1.0.16, Brzustowski 2015), that retained data as valid when at least three consecutive detections were separated by the transmitters' burst rate interval.

\section{Length of stay at nesting colonies}

Length of stay at the nesting colonies was calculated as the number of days between the estimated hatch date (if possible from individually monitored nests, or from median hatch dates at respective colonies; Table 2) and the last date an individual was detected by automated telemetry at a colony. We excluded nine nests from Petit Manan Island that failed prior to hatch (three Common Tern nests and six Arctic Tern nests).

For Common and Arctic Terns from colonies within the Gulf of Maine and Canada, we compared the length of stay in the colony by species and across colonies using a general linear model (function "lm" in base R version 3.0.2; R Core Team 2015). Model fit (normality and homoscedasticity of errors) were assessed using residuals plots. We included species (Arctic or Common Tern), and nesting colony (Petit Manan Island, Country Island, or Sable Island) along with the two-way interaction between those terms. The Monomoy colony was excluded from this analysis because Arctic Terns were not present at this site, and Common Tern sample size was considerably larger at Monomoy $(n=72)$ than at other sites $(n=14-29)$. We used posthoc Tukey tests (R package "multcomp," version 1.4-4, Hothorn et al. 2015) to determine which colonies were significantly different $(p<0.05)$ for all comparisons. For Common Terns only, we used a $t$-test to compare length of stay within the nesting colony between colonies in the Gulf of Maine and Canada (pooled) versus Common Terns from the South Monomoy Island colony in Nantucket Sound. We conducted this additional comparison to test for differences in length of stay from Common Terns versus northern and southern colonies within our study area.

\section{Dispersal and staging}

We assessed differences in postbreeding dispersal and staging between the two species by comparing detections of each at known (Nantucket Sound) or possible (Sable Island) staging areas. We define staging as detection of an individual for greater than $24 \mathrm{~h}$ at a site other than its breeding colony, and define postbreeding dispersal as detections at noncolony sites following departure from the nesting colony. Although individuals from South Monomoy Island may also stage in Nantucket Sound, we do not assess "staging" of these individuals because it was not possible to distinguish between dispersal and local postbreeding movements at this scale. On Sable Island, we assessed staging by examining the timing of detections of receiver stations at the eastern and western ends of the island that were situated $\sim 15 \mathrm{~km}$ from breeding colonies on the island (Fig. 1).

We then used logistic regression to estimate the probability of dispersal to the Nantucket Sound staging area by Common Terns among the three other breeding colonies. The binary dependent variable was coded as 1 for individuals that staged in Nantucket Sound and 0 for individuals that did not. The independent variables were nesting colony (Petit Manan Island, Country Island, or Sable Island) and length of stay in the nesting colony during the postfledging period (in days). Models were fit using function glm with a binomial family and logit link, in base R (version 3.0.2, R Core Development Team 2015). We used a likelihood ratio test (Hosmer and Lemeshow 2000) to determine whether there was any evidence that either independent variable influenced the probability an individual was detected staging in Nantucket Sound.

Finally, we calculated summary statistics of the distance and duration of postbreeding dispersal movements detected by the array. We calculated the distance of dispersal movements as the Euclidian distance traveled between the nesting colony and noncolony sites during the postbreeding dispersal period. We calculated a maximum travel time as the number of days between the last detection at the colony and the first detection at postbreeding dispersal sites. We calculated length of stay at postbreeding dispersal sites as the total amount of time (in days) between the first and last detection recorded by automated radio telemetry station(s) at each site. For all birds, we assumed that the timing of their final observations coincided with departure from the study area. Estimates of length of stay at and departure dates from the nesting colonies and postbreeding dispersal sites are minima because we cannot measure tag failure or loss after the birds have left the nesting colony.

\section{Diel variation in movements}

We calculated mean departure times (on a 24-hour clock) and mean resultant length of timing of key movements ( $\rho$, a measure of dispersion of a sample of directional measurements) using $\mathrm{R}$ package "Circular" (v. 0.4-7, Agostinelli and Lund 2013) and used those data to summarize: (1) arrival times of Common Terns at staging sites; (2) timing of detections of postbreeding movements of Arctic Terns; and (3) departure times from the study area for both species. 
Table 2. Median and range of dates of transmitter deployment, estimated hatch dates of nests, and final date in study area of digital VHF-tagged Common (Sterna hirundo; $n=120$ ) and Arctic (S. paradisaea; $n=51)$ Terns from four nesting colonies in the western North Atlantic in 2013.

\begin{tabular}{|c|c|c|c|c|c|c|}
\hline \multirow[b]{2}{*}{ Colony } & \multicolumn{2}{|c|}{ Tag dates (median and range) } & \multicolumn{2}{|c|}{ Hatch dates (median and range) } & \multicolumn{2}{|c|}{$\begin{array}{c}\text { Final date in study area (median and } \\
\text { range) }\end{array}$} \\
\hline & Common & Arctic & Common & Arctic & Common & Arctic \\
\hline Petit Manan Is. & $6 / 13(6 / 13-6 / 21)$ & $6 / 13(6 / 13-6 / 20)$ & $6 / 26(6 / 22-6 / 30)$ & $6 / 24(6 / 20-7 / 20)$ & $7 / 23(6 / 28-8 / 19)$ & $7 / 23(6 / 27-8 / 17)$ \\
\hline Country Is. & $6 / 15(6 / 14-7 / 4)$ & $6 / 15(6 / 14-7 / 14)$ & $6 / 26(6 / 23-7 / 20)$ & $6 / 24(6 / 20-7 / 20)$ & $7 / 9(6 / 23-8 / 18)$ & $7 / 30(6 / 28-8 / 14)$ \\
\hline Sable Is. & $6 / 10(6 / 9-6 / 13)$ & $6 / 10(6 / 9-6 / 11)$ & $6 / 24^{\dagger}$ & $6 / 24^{\dagger}$ & $7 / 20(6 / 20-9 / 7)$ & $7 / 30(6 / 19-8 / 10)$ \\
\hline Monomoy Is & $6 / 20(6 / 4-7 / 6)$ & -- & $6 / 21(6 / 15-7 / 15)$ & --- & $8 / 5(7 / 4-9 / 15)$ & --- \\
\hline
\end{tabular}

${ }^{\dagger}$ On Sable Island, individual nests were not monitored so assumed mean hatch date of $6 / 24$

\section{RESULTS}

\section{Tag retention}

Of 182 deployed transmitters, 13 transmitters ( $7 \%$ ) were dropped before individuals departed their nesting colony ( 2 of which were redeployed), with Country Island having disproportionately higher rates of confirmed tag loss $\left(\chi^{2}=41.19, \mathrm{df}=9, p<0.001\right)$. This resulted in a total of 171 tags (120 Common Terns and 51 Arctic Terns) that were included in the final analyses (Table 1). Mean tracking duration within the study array was approximately $40 \mathrm{~d} \pm 17$ (range 7 to $97 \mathrm{~d}$ ), although total retention duration cannot be quantified once birds departed the study area of the telemetry array.

\section{Length of stay}

For terns from colonies in the Gulf of Maine and Canada, length of stay at the colony differed significantly between Arctic and Common Terns $\left(F_{1,87}=6.312, p=0.014\right)$ but not among colonies $\left(F_{2,87}=1.439, p=0.334\right)$. Overall, mean $( \pm \mathrm{SE})$ length of stay at the colony was about 8 days longer for Arctic Terns (29 days \pm 2 days, range -5 to 48 days) than Common Terns (21 days \pm 2 days, range -5 to 71 days). For Common Terns, when comparing length of stay at the nesting colony between colonies in the Gulf of Maine and Canada versus South Monomoy Island, length of stay was significantly longer $\left(T_{117}=5.992, p<0.001\right)$ for birds from South Monomoy Island.

For Common and Arctic Terns from colonies in the Gulf of Maine and Canada, mean departure date from the study area was 22 July (range 19 Jun to $7 \mathrm{Sep}$ ) and did not differ significantly among colonies $\left(F_{2,96}=0.261, p=0.771\right)$ or $\operatorname{species}\left(F_{1,96}=1.133, p=\right.$ 0.290; Table 2). Common Terns from Nantucket Sound departed from the study area significantly later $\left(t_{117}=5.91, p<0.001\right)$ relative to Common Terns from colonies in the Gulf of Maine and Canada (Table 2).

\section{Dispersal of Common Terns}

On Sable Island 9 of $28(32 \%)$ Common Terns breeding at this site used the east or west ends of the island during the breeding period, however, during the postbreeding period no tagged individuals used the east end and only two were detected at the west end. Only one individual showed clear evidence of staging behavior at the west end: following the last detection at the colony, this bird was detected almost daily from 17 August to 10 September. No Common Terns from Country Island, Petit Manan Island, or Nantucket Sound were detected staging on Sable Island.
Overall, $26 \%$ of Common Terns from the three colonies in the Gulf of Maine and Canada were detected in Nantucket Sound during dispersal (Fig. 2). The colony at South Monomoy Island occurs within the Nantucket Sound staging area, therefore we do not assess the proportion of birds using this site as a postbreeding staging area. The probability of dispersal to Nantucket Sound was positively related to length of stay at the nesting colony (Likelihood Ratio Test: $\chi^{2}=38.341, n=52, p<0.001$ ) but did not differ among nesting colonies (Likelihood Ratio Test: $\chi^{2}=60.26$, $n=52, p=0.854)$. Individuals that left the nesting colony around 4 days after the fledge date of their chicks had a $25 \%$ probability of being detected in Nantucket Sound whereas those that remained for 24 days had a $75 \%$ probability of being detected. Travel times and Euclidean travel distances of postbreeding dispersal movements between colonies and Nantucket Sound are presented in Table 3.

Fig. 2. Euclidian postbreeding movements of tagged Common Terns (Sterna hirundo; $n=120$ ) from four nesting colonies in the northwest Atlantic, Petit Manan Island, Maine, USA (red); Country Island, Nova Scotia, Canada (yellow); Sable Island, Nova Scotia, Canada (green); and South Monomoy Island, Massachusetts, USA (blue), tracked by 62 automated radio telemetry stations during the 2013 postbreeding dispersal period. Black arrows show generalized direction of travel.

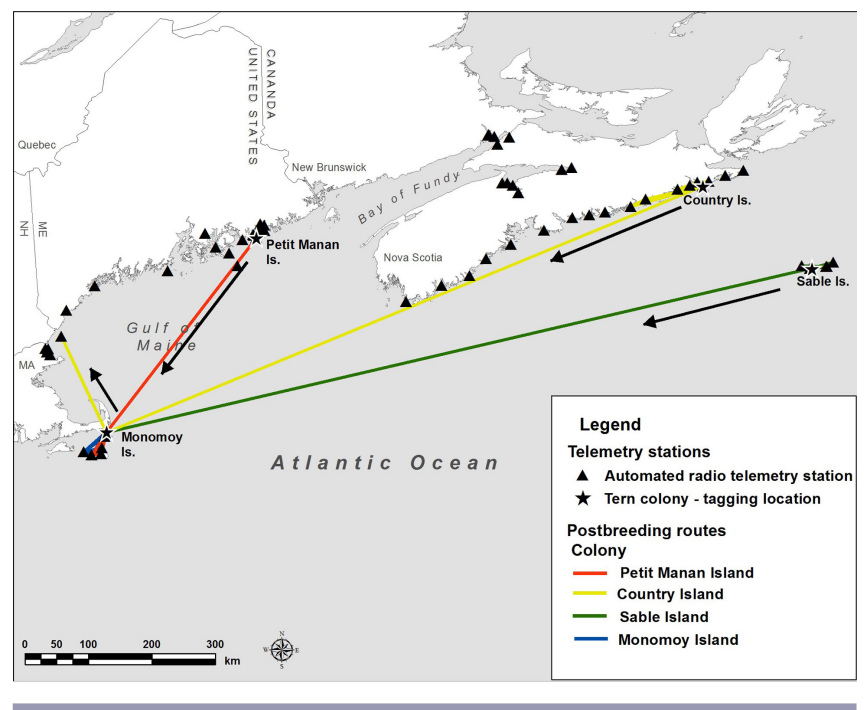


Table 3. Mean ( \pm SE and range) distance traveled $(\mathrm{km})$ to postbreeding dispersal sites, duration (in days) of postbreeding dispersal movements (assuming Euclidian distances), length of stay (mean \pm SE and range, in days), and dates (median and range) of arrival and departure at postbreeding dispersal sites of Common Terns (Sterna hirundo) from three nesting colonies throughout the western North Atlantic in 2013.

\begin{tabular}{|c|c|c|c|c|c|}
\hline Colony & $\begin{array}{l}\text { Minimum distance } \\
\text { traveled }(n=14)\end{array}$ & $\begin{array}{l}\text { Trip duration } \\
\qquad(n=14)\end{array}$ & $\begin{array}{c}\text { Arrival date } \\
\text { (median, range; } \\
n=53 \text { ) }\end{array}$ & $\begin{array}{c}\text { Departure date } \\
\text { (median, range; } \\
\quad n=53 \text { ) }\end{array}$ & $\begin{array}{l}\text { Length of stay } \\
\qquad(n=53)\end{array}$ \\
\hline Petit Manan Is. & $\begin{array}{c}356 \\
( \pm 3 ; 352-361)\end{array}$ & $\begin{array}{c}3.54 \\
( \pm 0.87 ; 1.77-5.75)\end{array}$ & $\begin{array}{c}8 / 4 \\
(7 / 26-8 / 6)\end{array}$ & $\begin{array}{c}8 / 12 \\
(8 / 7-8 / 19)\end{array}$ & $\begin{array}{c}10.20 \\
( \pm 4.41 ; 4.04-23.28)\end{array}$ \\
\hline Country Is. & $\begin{array}{c}556 \\
( \pm 199 ; 160-786)\end{array}$ & $\begin{array}{c}2.35 \\
( \pm 0.44 ; 1.48-2.83)\end{array}$ & $\begin{array}{c}8 / 10 \\
(8 / 6-8 / 13)\end{array}$ & $\begin{array}{c}8 / 16 \\
(8 / 14-8 / 18)\end{array}$ & $\begin{array}{c}6.36 \\
( \pm 1.43 ; 4.92-7.79)\end{array}$ \\
\hline Sable Is. & $\begin{array}{c}867 \\
( \pm 5 ; 851-891) \\
\end{array}$ & $\begin{array}{c}5.54 \\
( \pm 0.93,2.63-10.00)\end{array}$ & $\begin{array}{c}8 / 11 \\
(7 / 26-9 / 6) \\
\end{array}$ & $\begin{array}{c}8 / 12 \\
(7 / 27-9 / 7)\end{array}$ & $\begin{array}{c}2.47 \\
( \pm 0.9 ; 0.01-7.68)\end{array}$ \\
\hline
\end{tabular}

Common Terns from colonies in the Gulf of Maine and Canada arrived in Nantucket Sound between 26 July and 6 Sep, and departed from Nantucket Sound between 7 Aug and 7 Sep (Appendix 1). Mean ( \pm SE) length of stay of Common Terns ( $n$ $=14)$ in Nantucket Sound was 5.24 days ( \pm 1.58 days; range $<1$ to 23.28 days; Table 3). All of the terns that dispersed to Nantucket Sound area were detected at South Monomoy Island, with some birds remaining for up to three weeks (Appendix 1). With the exception of one tern from Country Island, Common Terns that dispersed to Nantucket Sound were not detected again by northern sites within our network of telemetry towers, indicating they likely departed southward from the region to continue migration. The one Country Island tern staged in Nantucket Sound for 2.75 days, and then flew approximately $160 \mathrm{~km}$ north to the Isle of Shoals in the Gulf of Maine where it was detected for approximately three hours before departing from the study area.

\section{Dispersal of Arctic Terns}

No Arctic Terns were detected at the Nantucket Sound staging area, and Arctic Terns from Sable Island and Country Island were never detected $>100 \mathrm{~km}$ from their nesting colonies. On Sable Island, 5 of 22 Arctic Terns (23\%) from this site were detected at the east or west ends of the island, but none were detected after 14 July, suggesting no evidence of postbreeding staging at these locations on the island. No Arctic Terns from Country Island, Petit Manan Island, or Nantucket Sound were detected staging on Sable Island.

Four of 15 Arctic Terns from Petit Manan Island (27\%) were detected at sites along the eastern coast of Nova Scotia during postbreeding period, between 25 July and 17 Aug (Fig 3). The final detections of all four Arctic Terns detected in Nova Scotia were short observations ( $<5$ minutes) as individuals passed within range of receiving stations. One of these individuals first travelled to the coast of Nova Scotia where it spent $\sim 3$ days before travelling back to the breeding colony for one day before again travelling back through coastal Nova Scotia. The mean $( \pm$ SE) minimum (Euclidian) distance traveled by Arctic Terns $(n=4)$ from Petit

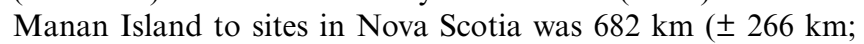
range 377 to $1,478 \mathrm{~km})$ and the mean ( $\pm \mathrm{SE}$ ) trip duration was 7.52 days ( \pm 2.85 days; range 1.00 to 17.90 days; Table 3 ).
Fig. 3. Euclidian postbreeding movements of tagged Arctic Terns (Sterna paradisaea; $n=52$ ) from three nesting colonies in the northwest Atlantic, Petit Manan Island, Maine, USA (red); Country Island, Nova Scotia, Canada (yellow); and Sable Island, Nova Scotia, Canada (green), tracked by 62 automated radio telemetry stations during 2013 . Black arrows show generalized direction of travel.

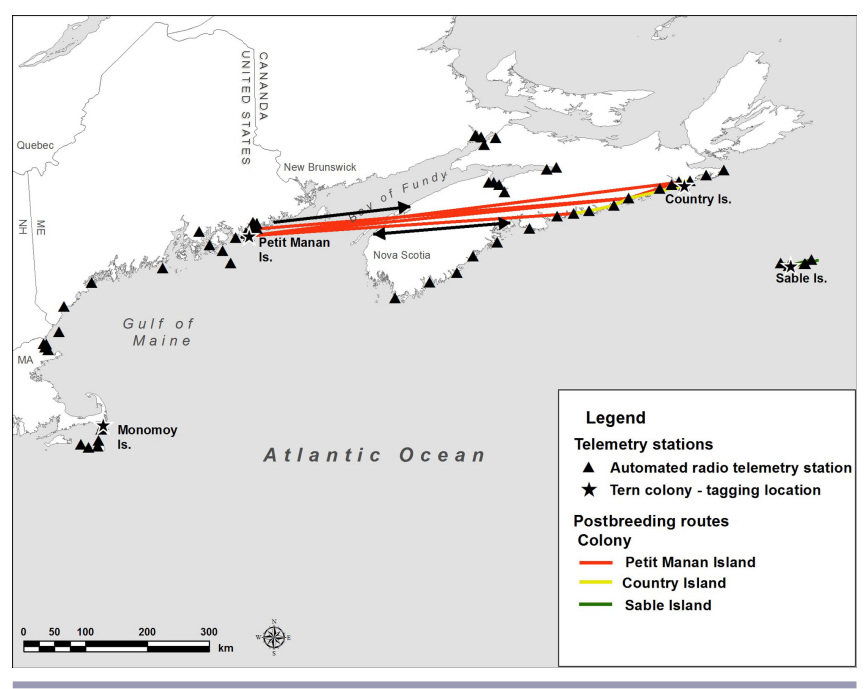

\section{Timing of postbreeding movements}

Common Terns from colonies in the Gulf of Maine and Canada arrived at staging areas in Nantucket Sound between 15:00 hrs and 05:00 hrs, peaking within two hours of sunset (Fig. 4). Arctic Terns were detected passing by the coast of Nova Scotia at night, between 22:00 hrs and 04:00 hrs (Fig. 5). Across all terns in the study $(n=182)$, timing of departure from the study area most commonly occurred just before sunrise, with a unimodal distribution that had a mean departure time of $04: 49 \mathrm{hrs}(\rho=$ 0.175; Figs. 6 and 7).

\section{DISCUSSION}

Using an automated international telemetry array and VHF tracking technology, this study offered new insights into the migratory behavior of two seabird species from breeding sites in 
Fig. 4. Diel variation (hrs, in local time) in arrival times of Common Terns (Sterna hirundo; $n=14$ ) from three nesting colonies in the northwest Atlantic (Petit Manan Island, Maine, USA; Country Island, Nova Scotia, Canada; and Sable Island, Nova Scotia, Canada) at staging areas in Nantucket Sound, Massachusetts, USA during 2013. Dashed lines show local times of sunrise (orange) and sunset (blue).

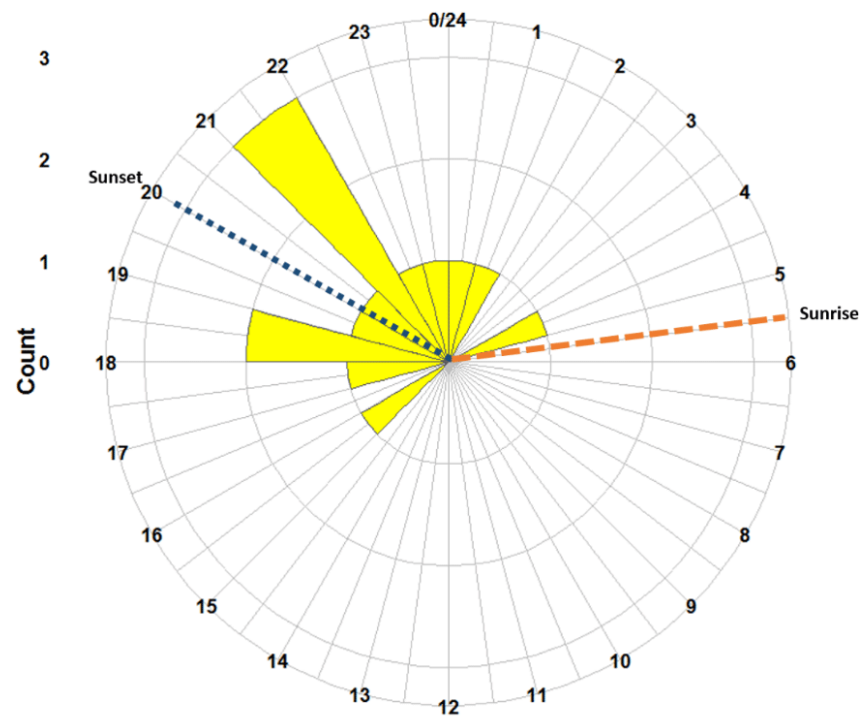

Fig. 5. Diel variation (hrs, in local time) in passage times of Arctic Terns (Sterna paradisaea; $n=4$ ) from Petit Manan Island, Maine, USA passing through sites in Nova Scotia, Canada during the postbreeding period in 2013. Dashed lines show local times of sunrise (orange) and sunset (blue).

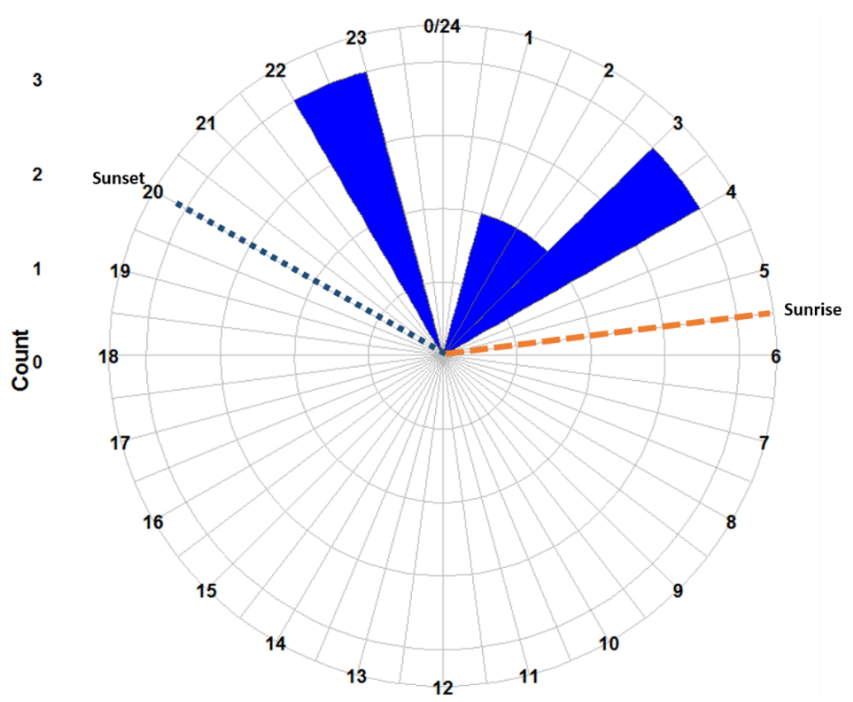

Fig. 6. Diel variation (hrs, local time) of postbreeding departure times of Common Terns (Sterna hirundo; $n=120$ ) from western North Atlantic study area during 2013. Dashed lines show local times of sunrise (orange) and sunset (blue).

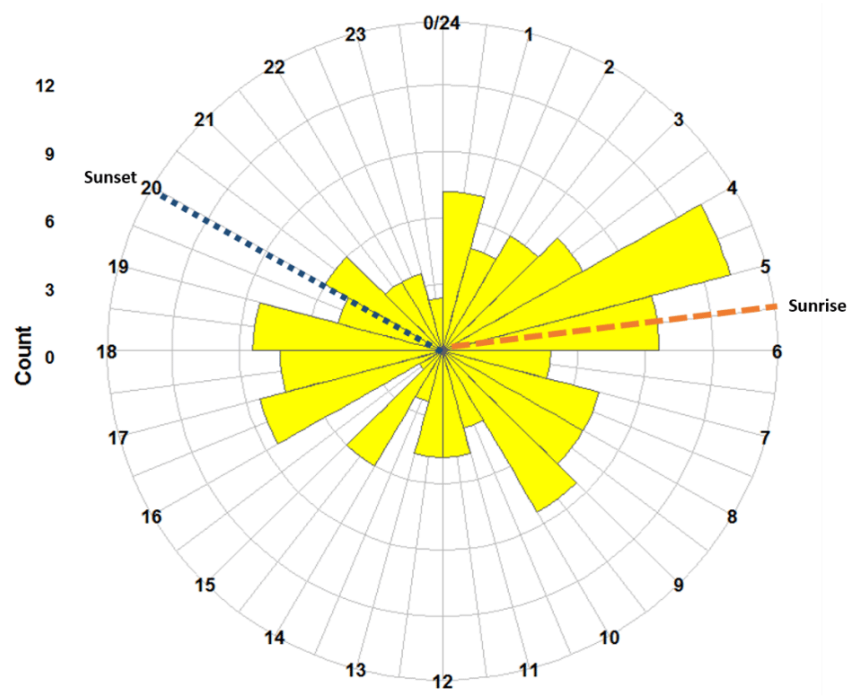

Fig. 7. Diel variation (hrs, local time) of postbreeding departure times of Arctic Terns (Sterna paradisaea; $n=52$ ) from western North Atlantic study area during 2013. Dashed lines show local times of sunrise (orange) and sunset (blue).

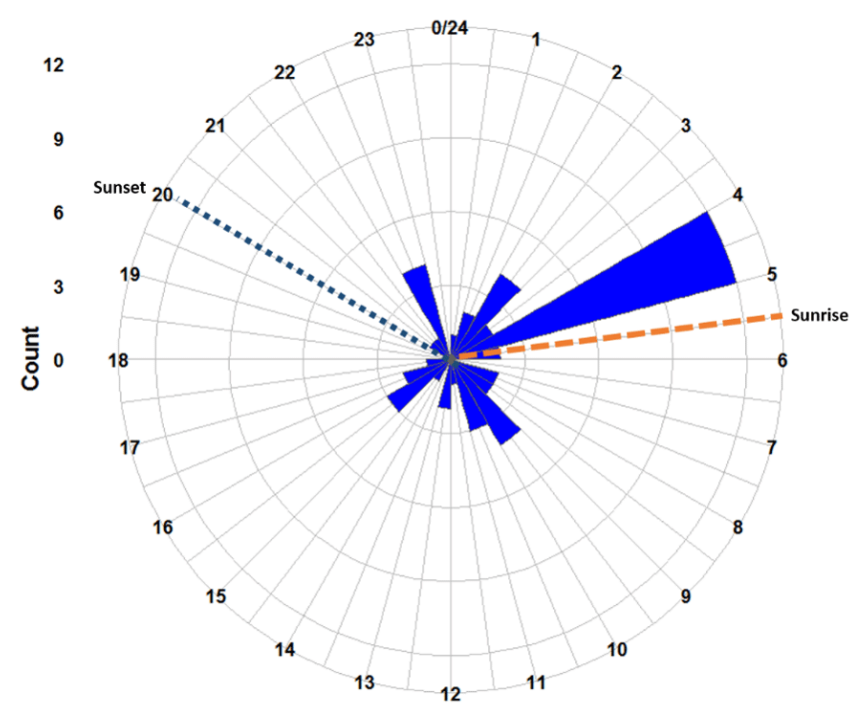


the western North Atlantic. We documented connectivity among nesting sites in the Gulf of Maine and Canada for Common Terns and a staging site in Massachusetts, USA; a lack of detections during transit suggests direct open-water crossing between breeding colonies and this site. In contrast, the general paucity of detections of Arctic Terns by the array suggests this species is not using coastal staging areas and is possibly transiting directly to offshore staging areas used by Arctic Terns from other regions (e.g., Egevang et al. 2010). From a behavioral perspective, our data show that both tern species initiate postbreeding movements principally at night, typically within two hours prior to sunrise.

Our results showed variation in length of stay of terns by species. Among Common and Arctic Terns, timing of fledging typically varied between 21 to 29 days after eggs hatched and successful breeders dispersed away from their colonies between 10 to 20 days after chicks fledged (Nisbet 1976, Hatch 2002). Failed breeders may depart from the colony within days following nest loss (Loring et al. 2016) while others may remain as long as breeders (Nisbet et al. 2011a). However, because of incomplete productivity data across our study sites, we were unable to relate departure date to reproductive success of individual birds in this analysis. Among the three colonies where both species were tagged, we observed that Arctic Terns departed, on average, eight days later than Common Terns. This difference may reflect the tern's differing migratory strategies. Common Terns departed early for known staging areas in Nantucket Sound, while Arctic Terns, which may need to replenish body reserves locally at colony sites, delayed departure for their pelagic staging and migratory routes (Egevang et al. 2010, this study). Among Common Tern study sites, South Monomoy Island birds showed a longer length of stay compared to the three northern colonies, perhaps reflecting latitudinal effects. However, it is more likely that this longer stay was due to the availability of suitable staging habitat at Monomoy that could therefore prolong their colony attendance. It is also likely that some apparent departures prior to estimated fledge dates was due to tag loss or malfunction, which may have varied among colonies or species. We attempted to control for this by removing known dropped transmitters ( $7 \%$ of deployments) from analyses, but it is possible that additional birds dropped their transmitters beyond the range of the telemetry array prior to colony departure, and thus were not accounted for as dropped. As a consequence, estimates of length of stay at the colony and proportions of terns that staged in the Nantucket Sound region should be considered a minimum.

During the postbreeding period (July and August), Common and Roseate Terns from nesting colonies in the western North Atlantic may disperse hundreds of kilometers to staging areas throughout the region (Austin 1953, Shealer and Kress 1994, Trull et al. 1999). We found that, from late July to early September, our tagged Common Terns from northern colonies dispersed up to $800 \mathrm{~km}$ to staging areas in Nantucket Sound, and that their mean travel time ( $<1$ week) was shorter relative to the dispersal of Roseate Terns across similar distances reported by other studies (mean travel time $>3$ weeks; Shealer and Kress 1994). The locations of telemetry receivers in 2013, with limited coastal coverage along the coast of southwestern Nova Scotia and the western Gulf of Maine, did not allow us to distinguish whether individuals used coastal or offshore routes or whether there are additional staging sites in the region.
During the postbreeding period, South Monomoy Island within Nantucket Sound is considered an important staging area for several species of terns in eastern North America, because of its remote location with relatively low levels of human disturbance, large area of sand flats available for roosting, and proximity to foraging areas that include extensive shoals (Trull et al. 1999). The prolonged use of this location by nesting Common Terns tagged in this study align with the findings of Trull et al. (1999), where the majority of staging terns in the Cape Cod and Nantucket Sound region used South Monomoy Island and an adjacent barrier beach as nocturnal roosting areas. We found that a minimum of $25 \%$ of our tagged Common Terns from Gulf of Maine and Canadian tern colonies dispersed to South Monomoy Island during the postbreeding period, including some individuals that remained here for up to three weeks, further highlighting the importance of South Monomoy Island for postbreeding terns within the western North Atlantic Ocean.

Common Terns that staged in Nantucket Sound departed from the region between mid-August and early September, which is consistent with past studies (Veit and Petersen 1993, Trull et al. 1999). Using geolocators, Nisbet et al. (2011b) found that the mean autumn migration date of female Common Terns from the southern New England area was in mid-August, while the mean date for males was in early September. Most terns that staged in Nantucket Sound appeared to depart from the study area from that region, with the exception of one individual that was detected flying from Nantucket Sound to the Gulf of Maine prior to departure. Northern movements of terns from the southern New England region to sites in Gulf of Maine during the postbreeding period has been documented previously for Common Terns (Austin 1953) and Roseate Terns (Shealer and Kress 1994). We did not document movements of Common Terns from other colonies to Sable Island, but we found some evidence (1 of 28 birds) of a local breeding bird staging there until 10 September.

With the exception of eastward movements of Arctic Terns from Petit Manan Island that were detected passing through sites in Nova Scotia, we were unable to assess the postbreeding dispersal of Arctic Terns with the telemetry array. This suggests that Arctic Terns are not using coastal sites for staging (within the array of telemetry sites) and are instead departing for offshore staging or migration routes directly from their colonies. This was not entirely unexpected because prior research to document Arctic Tern migration using geolocators demonstrated that Arctic Terns from colonies in the Gulf of Maine traveled north-northeast after nesting, then migrated east across the Atlantic Ocean (L. Welch, unpublished data). Geolocator studies of Arctic Terns tagged from colonies in Greenland and Iceland revealed that during postbreeding dispersal, individuals traveled to a pelagic stopover region in the eastern Newfoundland Basin and western slope of mid-North Atlantic Ridge ( 41 to $53^{\circ} \mathrm{N}$ and 27 to $41^{\circ} \mathrm{W}$ ) where they spent an average of three weeks prior to migrating southeast toward the coast of Africa (Egevang et al. 2010).

Colony departure movements of both species were initiated primarily at night during this study. There is little empirical evidence of the precise timing of tern movements within the literature, but observational and radar data indicate that terns initiate migratory movement at dusk and fly at migratory altitudes 
(1000 to $3000 \mathrm{~m}$ ) during night (Alerstam 1985, Veit and Petersen 1993). We found that, for both Common and Arctic Terns, departure times from the study area peaked just before dawn (04:00 to $05: 00 \mathrm{hrs}$ ). It is possible that these departure times coincided with morning foraging flights because peak foraging activity largely occurs during morning hours (Burger and Gochfeld 1991, Galbraith et al. 1999). Better coverage of automated radio telemetry stations throughout their postbreeding range is needed to more precisely quantify timing of migratory movements using digital VHF technology.

\section{CONCLUSIONS}

Common and Arctic Terns from colonies in the western North Atlantic exhibit divergent strategies for dispersal. Nantucket Sound appears to be an important premigratory staging area for Common Terns from breeding colonies in the western North Atlantic. More information is needed on postbreeding movements of Arctic Terns to identify important offshore staging areas, although geolocator technology has provided evidence of offshore staging and stopover areas at relatively coarse temporal and spatial scales (Egevang et al. 2010, Duffy et al. 2013, McKnight et al. 2013). Additional automated radio telemetry stations, in both coastal and offshore areas, would be useful for more accurately tracking the postbreeding movements of Common and Arctic Terns in our study area.

Responses to this article can be read online at: http://www.ace-eco.org/issues/responses.php/1086

\section{Acknowledgments:}

This study was funded in part by the U.S. Department of the Interior, Bureau of Ocean Energy Management through Interagency Agreement M13PG00012 with the U.S. Department of the Interior, Fish and Wildlife Service. Work in Nantucket Sound was also funded in part by the U.S. Fish and Wildlife Service Division of Migratory Birds, Northeast Region; and the National Science Foundation IGERT Offshore Wind Energy Program with logistical support from Eastern Massachusetts National Wildlife Refuge Complex, the Nantucket Conservation Foundation, the Nantucket Island Land Bank, and the University of Rhode Island. Work on Country Island and Sable Island was funded by Encana Corporation Research and Development Fund, Natural Sciences and Engineering Research Council (NSERC) Collaborative Research and Development grant, Canadian Wildlife Federation, and Environment Canada, with in-kind support from Department of Fisheries and Oceans and the Meteorological Service of Canada. The manuscript benefited from the extensive comments of several anonymous referees. For advice, assistance, and support from all projects we thank the following individuals: Karen Beattie, Matt Boarman, John Brzustowski, Zoe Crysler, Danielle Fife, Curt Griffin, Sarah Gutowski, Kate Iaquinto, Scott Johnston, Brian Lang, Stephanie Koch, Peter Paton, Blair Perkins, Ingrid Pollet, Caleb Spiegel, Eric Savetsky, Paul Sievert, Jessica Stephens, Brett Still, and the field crew at Country Island. The findings and conclusions in this article are those of the author $(s)$ and do not necessarily represent the views of the U.S. Fish and Wildlife Service.

\section{LITERATURE CITED}

Agostinelli, C., and U. Lund. 2013. Circular: circular statistics. R package version 0.4-7 edition. R Foundation for Statistical Computing, Vienna, Austria.

Alerstam, T. 1985. Strategies of migratory flight, illustrated by Arctic and Common Terns, Sterna paradisaea and Sterna hirundo. Contributions in Marine Science Supplement 27:580-603.

Althouse, M. A., J. B. Cohen, J. A. Spendelow, S. M. Karpanty, K. L. Davis, K. C. Parsons, and C. F. Luttazi. 2016. Quantifying the effects of research band resighting activities on staging terns in comparison to other disturbances. Waterbirds 39:417-421. http://dx.doi.org/10.1675/063.039.0412

Austin, O. L. 1928. Migration-routes of the Arctic Tern. Bulletin of the Northeast Bird Banding Association 4:121-125.

Austin, O. L. 1953. The migration of the Common Tern (Sterna hirundo) in the Western Hemisphere. Bird-Banding 24:39-55. http://dx.doi.org/10.2307/4510414

Braune, B. M., and D. E. Gaskin. 1982. Feeding ecology of nonbreeding populations of Larids off Deer Island, New Brunswick. Auk 99:67-76. http://dx.doi.org/10.2307/4086022

Bridge, E. S., K. Thorup, M. S. Bowlin, P. B. Chilson, R. H. Diehl, R. W. Fléron, P. Hartl, R. Kays, J. F. Kelly, W. D. Robinson, and M. Wikelski. 2011. Technology on the move: recent and forthcoming innovations for tracking migratory birds. BioScience 61:689-698. http://dx.doi.org/10.1525/bio.2011.61.9.7

Brzustowski, J. 2015. SensorGnome. R package version 1.0.16. R Foundation for Statistical Computing, Vienna, Austria.

Burger, J., and M. Gochfeld. 1991. The Common Tern: its breeding biology and social behavior. Columbia University Press, New York, New York, USA.

Duffy, D. C., A. McKnight, and D. B. Irons. 2013. Trans-Andean passage of migrating Arctic Terns over Patagonia. Marine Ornithology 41:155-159.

Egevang, C., I. J. Stenhouse, R. A. Phillips, A. Petersen, J. W. Fox, and J. R. D. Silk. 2010. Tracking of Arctic Terns (Sterna paradisaea) reveals longest animal migration. Proceedings of the National Academy of Sciences 107:2078-2081. http://dx.doi. org/10.1073/pnas.0909493107

Galbraith, H., J. J. Hatch, I. C. T. Nisbet, and T. H. Kunz. 1999. Age-related changes in efficiency among breeding Common Terns Sterna hirundo: measurement of energy expenditure using doubly-labelled water. Journal of Avian Biology 30:85-96. http:// dx.doi.org/10.2307/3677247

Gaston, A. J., D. F. Bertram, A. W. Boyne, J. W. Chardine, G. Davoren, A. W. Diamond, A. Hedd, W. A. Montevecchi, J. M. Hipfner, M. J. F. Lemon, M. L. Mallory, J.-F. Rail, and G. J. Robertson. 2009. Changes in Canadian seabird populations and ecology since 1970 in relation to changes in oceanography and food webs. Environmental Reviews 17:267-286. http://dx.doi. org/10.1139/A09-013

Gilg, O., B. Moe, S. A. Hanssen, N. M. Schmidt, B. Sittler, J. Hansen, J. Reneerkens, B. Sabard, O. Chastel, J. Moreau, R. A. Phillips, T. Oudman, E. M. Biersma, A. A. Fenstad, J. Lang, and 
L. Bollache. 2013. Trans-equatorial migration routes, staging sites and wintering areas of a High-Arctic avian predator: the Longtailed Skua (Stercorarius longicaudus). PLoS ONE 8:e64614. http://dx.doi.org/10.1371/journal.pone.0064614

Guilford, T., J. Meade, J. Willis, R. A. Phillips, D. Boyle, S. Roberts, M. Collett, R. Freeman, and C. M. Perrins. 2009. Migration and stopover in a small pelagic seabird, the Manx Shearwater (Puffinus puffinus): insights from machine learning. Proceedings of the Royal Society of London B: Biological Sciences 276:1215-1223. http://dx.doi.org/10.1098/rspb.2008.1577

Gulf of Maine Seabird Working Group (GOMSWG). 2013.2013 Gulf of Maine Seabird Working Group census results. GOMSWG, Bangor, Maine, USA. [online] URL: http://gomswg.org/pdf_files/ GOMSWG\%20Census\%20Data\%202013.pdf

Hall, C. S., S. W. Kress, and C. R. Griffin. 2000. Composition, spatial and temporal variation of Common and Arctic Tern chick diets in the Gulf of Maine. Waterbirds 23:430-439. http://dx.doi. org/10.2307/1522180

Hatch, J. J. 2002. Arctic Tern (Sterna paradisaea). In A. Poole, editor. The birds of North America online. Cornell Lab of Ornithology, Ithaca, New York, USA. http://dx.doi.org/10.2173/ bna. 707

Hays, H., J. DiCostanzo, G. Cormons, P. T. Z. Antas, and J. L. X. do Nascimento. 1997. Recoveries of Roseate and Common Terns in South America. Journal of Field Ornithology 68:79-90.

Hedd, A., W. A. Montevecchi, H. Otley, R. A. Phillips, and D. A. Fifield. 2012. Trans-equatorial migration and habitat use by Sooty Shearwaters (Puffinus griseus) from the South Atlantic during the nonbreeding season. Marine Ecology Progress Series 449:277-290. http://dx.doi.org/10.3354/meps09538

Hosmer, D. W., and S. Lemeshow. 2000. Applied logistic regression. Second edition. John Wiley and Sons, New York, New York, USA. http://dx.doi.org/10.1002/0471722146

Hothorn, T., F. Bretz, and P. Westfall. 2015. Multcomp. R package version 1.4-4 edition. R Foundation for Statistical Computing, Vienna, Austria.

Huettmann, F., and A. W. Diamond. 2000. Seabird migration in the Canadian northwest Atlantic Ocean: moulting locations and movement patterns of immature birds. Canadian Journal of Zoology 78:624-647. http://dx.doi.org/10.1139/z99-239

Jedrey, E. L., R. J. Harris, and E. A. Ray. 2010. Roseate Terns citizens of the world: the Canada to Cape Cod connection. Bird Observer 38:146-150.

Klaassen, R. H. G., B. J. Ens, J. Shamoun-Baranes, K.-M. Exo, and F. Bairlein. 2012. Migration strategy of a flight generalist, the Lesser Black-backed Gull (Larus fuscus). Behavioral Ecology 23:58-68. http://dx.doi.org/10.1093/beheco/arr150

Kress, S. W., E. H. Weinstein, I. C. T. Nisbet, G. W. Shugart, W. C. Scharf, H. Blokpoel, G. A. Smith, K. Karwowski, G. R. Maxwell, G. Chapdelaine, W. A. Montevecchi, A. R. Lock, C. F. Smith, E. Miller, J. A. Spendelow, M. Gochfeld, J. Burger, and R. M. Erwin. 1983. The status of tern populations in northeastern United States and adjacent Canada. Colonial Waterbirds 6:84-106. http://dx.doi.org/10.2307/1520976
Lee, D. S. and S. W. Cardiff. 1993. Status of the Arctic Tern in the Coastal and Offshore Waters of the Southeastern United States (Estatus de Sterna paradisaea en la Costa y el Mar Adentro del Sureste de Los Estados Unidos). Journal of Field Ornithology 1993:158-168.

Loring, P. H. 2016. Evaluating digital VHF technology to monitor shorebird and seabird use of offshore wind energy areas in the western North Atlantic. Dissertation. University of Massachusetts Amherst, Amherst, Massachusetts, USA.

McKnight, A., A. J. Allyn, D. C. Duffy, and D. B. Irons. 2013. 'Stepping stone' pattern in Pacific Arctic Tern migration reveals the importance of upwelling areas. Marine Ecology Progress Series 491:253-264. http://dx.doi.org/10.3354/meps10469

Montevecchi, W. A., A. Hedd, L. McFarlane Tranquilla, D. A. Fifield, C. M. Burke, P. M. Regular, G. K. Davoren, S. Garthe, G. J. Robertson, and R. A. Phillips. 2012. Tracking seabirds to identify ecologically important and high risk marine areas in the western North Atlantic. Biological Conservation 156:62-71. http:// dx.doi.org/10.1016/j.biocon.2011.12.001

Mosbech, A., K. L. Johansen, N. I. Bech, P. Lyngs, A. M. Harding, C. Egevang, R. A. Phillips, and J. Fort. 2012. Inter-breeding movements of Little Auks (Alle alle) reveal a key post-breeding staging area in the Greenland Sea. Polar Biology 35:305-311. http://dx.doi.org/10.1007/s00300-011-1064-4

Nisbet, I. C. T. 1976. Early stages in postfledging dispersal of Common Terns. Bird-Banding 47:163-164. http://dx.doi. org/10.2307/4512218

Nisbet, I. C. T. 2002. Common Tern (Sterna hirundo). In A. Poole, editor. The birds of North America online Cornell Lab of Ornithology, Ithaca, New York, USA. http://dx.doi.org/10.2173/ bna.comter.03

Nisbet, I. C. T., C. S. Mostello, R. R. Veit, J. W. Fox, and V. Afanasyev. 2011a. Migrations and winter quarters of five Common Terns tracked using geolocators. Waterbirds 34:32-39. http://dx.doi.org/10.1675/063.034.0104

Nisbet, I. C. T., P. Szczys, C. S. Mostello, and J. W. Fox. $2011 b$. Female Common Terns (Sterna hirundo) start autumn migration earlier than males. Seabird 24:103-106.

R Development Core Team. 2015. R: a language and environment for statistical computing. R Foundation for Statistical Computing, Vienna, Austria.

Rock, J. C., M. L. Leonard, and A. W. Boyne. 2007. Do co-nesting Arctic and Common Terns partition foraging habitat and chick diets? Waterbirds 30:579-587. http://dx.doi.org/10.1675/1524-4695 (2007)030[0579:DCAACT]2.0.CO;2

Ronconi, R. A., A. W. Boyne, C. Gjerdrum, and A. G. Horn, 2016a. Population status and ecology of seabirds on Sable Island. Pages 213-241 in W. Freedman, editor. Sable Island: explorations in ecology and biodiversity. Fitzhenry \& Whiteside, Markham, Ontario, Canada.

Ronconi, R. A., J. R. Stephens, Z. J. Crysler, I. L. Pollet, D. T. Fife, A. G. Horn, and P. D. Taylor. 2016b. Distribution, abundance and trends of gulls and terns breeding on Sable Island, Nova Scotia, Canada. Waterbirds 39:44-56. http://dx.doi. org/10.1675/063.039.sp111 
Salomonsen, F. 1967. Migratory movements of the Arctic Tern (Sterna paradisaea Pontoppidan) in the Southern Ocean. Biol Medd Dan Vid Selsk 24:1-42

Shealer, D. A., and S. W. Kress. 1994. Post-breeding movements and prey selection of Roseate Terns at Stratton Island, Maine. Journal of Field Ornithology 65:349-362.

Suryan, R. M., F. Sato, G. R. Balogh, K. D. Hyrenbach, P. R. Sievert, and K. Ozaki. 2006. Foraging destinations and marine habitat use of short-tailed albatrosses: a multi-scale approach using first-passage time analysis. Deep Sea Research Part II: Topical Studies in Oceanography 53:370-386. http://dx.doi. org/10.1016/j.dsr2.2006.01.012

Taylor, P. D., T. L. Crewe, S. A. Mackenzie, D. Lepage, Y. Aubry, Z. Crysler, G. Finney, C. M. Francis, C. G. Guglielmo, D. J. Hamilton, R. L. Holberton, P. H. Loring, G. W. Mitchell, D. Norris, J. Paquet, R. A. Ronconi, J. Smetzer, P. A. Smith, L. J. Welch, and B. K. Woodworth. 2017. The Motus Wildlife Tracking System: a collaborative research network to enhance the understanding of wildlife movement. Avian Conservation and Ecology 12(1):8. http://dx.doi.org/10.5751/ACE-00953-120108

Trull, P., S. Hecker, M. J. Watson, and I. C. T. Nisbet. 1999. Staging of Roseate Terns (Sterna dougallii) in the post-breeding period around Cape Cod, Massachusetts, USA. Atlantic Seabirds 1:145-158.

van der Winden, J., R. C. Fijn, P. W. van Horssen, D. GerritsenDavidse, and T. Piersma. 2014. Idiosyncratic migrations of Black Terns (Chlidonias niger): diversity in routes and stopovers. Waterbirds 37:162-174. http://dx.doi.org/10.1675/063.037.0205

Veit, R. R., and W. R. Petersen. 1993. Birds of Massachusetts. Massachusetts Audubon Society, Lincoln, Massachusetts, USA.

Warnock, N. 2010. Stopping vs. staging: the difference between a hop and a jump. Journal of Avian Biology 41:621-626. http://dx. doi.org/10.1111/j.1600-048X.2010.05155.X

Watson, M. J., and J. J. Hatch. 1999. Differences in foraging performance between juvenile and adult Roseate Terns at a premigratory staging area. Waterbirds 22:463-465 http://dx.doi. org/10.2307/1522125 
Appendix 1. Number of individuals detected $(n)$ and length of stay (mean \pm SE and

range, in days) at postbreeding dispersal sites in Nantucket Sound, MA of Common Terns

(Sterna hirundo; $n=14$ ) from three nesting colonies throughout the western North Atlantic.

\begin{tabular}{lccccc}
\hline Site & $n$ & $\begin{array}{c}\text { Mean } \\
\text { Length of } \\
\text { Stay (d) }\end{array}$ & SE & Min & Max \\
\hline \multicolumn{1}{c}{ Petit Manan colony } & & & & & \\
\hline Monomoy Is. & 4 & 9.29 & 4.20 & 4.02 & 21.83 \\
Great Point, Nantucket & 2 & 0.11 & $<0.01$ & 0.11 & 0.11 \\
Eel Point, Nantucket & 3 & $<0.01$ & $<0.01$ & $<0.01$ & $<0.01$ \\
Coatue Point & 2 & 0.01 & $<0.01$ & $<0.01$ & 0.01 \\
$\quad$ Country Island colony & & & & & \\
Monomoy Is. & 2 & 3.91 & 3.18 & 0.73 & 7.09 \\
Great Point, Nanutcket & 1 & 0.04 & --- & 0.04 & 0.04 \\
Muskeget Is. & 1 & 1.11 & -- & 1.11 & 1.11 \\
$\quad$ Sable Island colony & & & & & \\
Monomoy Is. & 8 & 1.82 & 0.94 & 0.00 & 7.68 \\
Great Point, Nanutcket & 3 & 0.01 & 0.01 & $<0.01$ & 0.02 \\
Coatue Point, Nantucket & 1 & 0.01 & --- & 0.01 & 0.01 \\
Eel Point, Nantucket & 1 & 0.03 & --- & 0.03 & 0.03 \\
Muskeget Is. & 1 & 0.01 & --- & 0.01 & 0.01 \\
\hline
\end{tabular}

